\title{
A MICRO ANALYSIS STUDY OF PRAGMATIC CONTENT IN INDONESIAN ELT TEXTBOOKS
}

\author{
Satrio Aji Pramono ${ }^{1}$, Eri Kurniawan ${ }^{2}$ \\ ${ }^{12}$ Universitas Pendidikan Indonesia \\ Corresponding Email: satriopower@yahoo.co.id
}

Received: $23^{\text {rd }}$ of March 2020, Accepted: $12^{\text {th }}$ of May 2020, Published: $25^{\text {th }}$ of June 2020

\begin{abstract}
This study aims to explore the frequency of pragmatic content occurrence represented as speech acts of thanking and apologizing in two Indonesian ELT textbooks: a prescribed textbook published by Ministry of National Education and a commercial textbook. Pragmatic content of two ELT Textbooks entitled When English Rings the Bell and English on Sky were analyzed using Martinez's Framework on Speech act of thanking and apologizing. The result indicated that a number of speech acts of thanking and apologizing have sufficiently provided by both prescribed and commercial textbook. However, while there are various strategies which can be used to perform speech acts of thanking and apologizing, both textbooks failed to take into account the inclusion of those strategies. It is therefore advisable for language teachers to employ other authentic language sources to enhance learners' pragmatic competence.
\end{abstract}

Keywords: Pragmatic content; ELT Textbooks, Speech acts

\begin{abstract}
Abstrak
Penelitian ini bertujuan untuk menemukan frekuensi kemunculan konten pragmatik yang direpresentasikan dalam bentuk tindak tutur berterimakasih dan meminta maaf dalam dua buku ajar pendidikan bahasa Inggris yaitu: buku ajar wajib yang diterbitkan oleh Kementerian Pendidikan dan buku ajar komersial. Konten pragmatik dari dua buku yang berjudul When English Rings a Bell dan English on Sky dianalisis menggunakan Kerangka milik Martinez mengenai tindak tutur berterimakasih dan meminta maaf. Hasil dari penelitian ini menunjukkan bahwa tindak tutur berterimakasih dan meminta maaf dimunculkan dengan jumlah yang cukup pada kedua buku. Namun demikian, ketika ada banyak strategi yang bisa digunakan untuk menciptakan tindak tutur berterimakasih dan meminta maaf, kedua buku yang diteliti kurang memberi perhatian pada hal tersebut. Oleh karena itu, pengajar bahasa Inggris disarankan untuk menggunakan sumber belajar bahasa otentik lainnya untuk meningkatkan kemampuan pragmatik siswa.
\end{abstract}

Kata Kunci: Konten pragmatik; Buku Ajar Bahasa Inggris, Tindak Tutur

Copyright (C) 2020 Satrio Aji Pramono, Eri Kurniawan

\section{INTRODUCTION}

To be able to conduct a successful communication, second language learners need to master particular competencies. When learning a foreign language, learners are not only dealing with the meaning of words or sentences but also pragmatic contents of the utterances they make which somehow becomes barrier in their learning process (Meihami \& Kanlarzadeh, 2015). This is to say that although a learner may be good in mastering vocabularies and their meanings as well as their usage in sentences, he or she may fail to express particular utterances in particular context (Brock \& Nagasaka, 2005). 
As language is not used in isolation, various factors take roles in the success of communication. Zhao \& Trossel (2011) suggest that learning a language means learning how to communicate in that language, and therefore successful communication between interlocutor lays upon proper speech acts: utterances that serve specific functions in communication. In line with that, Glaser (2009) suggests that high level of pragmatic competence in the target language has a constructive effect for successful communication within the L2 contexts, and one important aspect of pragmatic competence is understanding and production of speech acts and their appropriateness in a given situation (Cheng, 2005).

Given the fact that communication is about conveying meaning appropriately based on the context and situation, lacking pragmatic competence may lead to pragmatic failure and communication breakdown. Misunderstanding, miscommunication, and communication goals distortion are some results caused by the inability of interpreting communication (Lin, 2008). Therefore, pragmatic competence in communication is crucial and this kind of competence needs to be developed by learners when they are learning Language. Among many things second language learners need to learn, the skills of using language in contextual ways are vital such as thanking and apologizing. Thanking or expressions of gratitude are produced as a reaction to a previous action and have as an objective to restore the balance in the social relations between speaker and hearer (Perez, 2005). Thanking is seen as one of important skills needed to be taken into account by second language learners since somehow the obligation of thanking comes from the cultural convention which leads us to express gratitude for other people on the realization that they have done something good for us (Martinez, 2013). Another skill needed to be learnt by language learners is apologizing. It is an act that express regret for a past action or past behavior. People apologize when they realize that they have caused something to happen that is negative to someone else or because of unintended consequences of their acts. These two examples of speech acts are among various speech acts which need to be learnt by English language learners so as to be able to communicate in appropriate way. Moreover, as one of the aims of national education is to build the students character, teaching how to use the expressions of apology and gratitude is beneficial to attain the goal.

Given the above situation, English language learning is supposed to provide the opportunity for the learners to learn how to use language in a particular context. One of many ways of providing the opportunity is by exposing pragmatic content in English language learning context. As textbooks are considered central to the curriculum and syllabus in most classroom (Vellenga, 2004), ELT textbook can be used to provide pragmatic content which is 
useful for the learners. Textbooks provide the primary or perhaps the only form of linguistic input as they are less expensive and more accessible compared to other media (Kim \& Hall, 2002). Contents about pragmatics such as speech act, entailment, implicature, and politeness thus can be infused in the material provided in textbooks. Therefore, material developers need to take into account the important role of textbooks in promoting learners' pragmatic competence in L2 classroom settings (Diepenbroek \& Derwing, 2013)

Notwithstanding the importance of pragmatic content provision in textbooks, textbooks rarely provide enough information for learner to successfully acquire pragmatic competence (Wichien \& Aksornjarung, 2011). Based on several research, textbooks have been found not to incorporate all the necessary input they have to such as coverage of important aspect of speech acts (Salazar Campillo, 2007; Uso-Juan, 2007, Vellenga, 2004). Besides, textbooks may become a source of pragmatic failure (Vasquez \& Sharpless 2009) like providing misrepresentation of speech act realization in textbooks which commonly native speaker realize in a speech act (Bardovi-Harlig, 2001).

Given the importance of pragmatic content in ELT textbooks in providing the learners with comprehensive input in L2 learning, this study is aimed at exploring how pragmatic contents are distributed in ELT textbooks. There has been some research which focused on the analysis of pragmatic features/knowledge in English textbooks, especially those examining the pragmatic features existence, speech acts, and politeness strategies in English textbooks (Khoirunnisa, 2017; Delen \& Tavil 2010; Meihami \& Khanlarzadeh, 2015; Wichien \& Aksornjarung, 2011). However, few studies narrowED down their focus on particular speech acts such as thanking and apologizing. Therefore, this study aims to reveal the pragmatic feature which is represented as two speech acts of thanking and apologizing distributed in textbooks. Particularly, this study attempts to answer the following questions: (1) How frequent are the speech acts of thanking and apologizing in the prescribed textbook and the commercial textbook? , (2) How frequent are the strategies that can be used to perform the speech acts of thanking and apologizing in the prescribed ELT textbook?, and (3) How frequent are the strategies that can be used to perform the speech acts of thanking and apologizing in the commercial ELT textbook?

\section{METHOD}

The present study utilized pragmatic content analysis as a method to analyze the pragmatic content of EFL textbooks. Content analysis itself is a research method that attempts to make valid and reliable interpretations from the content of the observed texts. (Krippendorf, 2004). 
For the sake of pragmatic content analysis of the ELT textbooks, two ELT textbooks for Grade VII were chosen in this study. The first ELT textbook is a prescribed textbook which is developed by the Ministry of National Education entitled When English Rings a Bell which is written by Siti Wachidah, Asep Gunawan, Diyantari, and Yuli Rulani Khatimah (2017). The second ELT textbook is a commercial textbook entitled English on Sky which is written by Mukarto, Widya Kiswara, Sujatmiko BS, and Josephine SM (2017). The reason behind the selection of these books is because they both have implemented the 2013 Curriculum. The other reason is that these books are among ELT textbooks used by most EFL teachers in Indonesia.

To analyze the distribution of two speech acts of thanking and apologizing, two frameworks were used. To obtain the frequency of thanking in the ELT textbooks, this study applied Martínez's (2013) framework of speech acts of thanking. In this framework, speech act of thanking is divided into three categories: (1) declarative thanking such as I thank you for [Xp], I am grateful for [Xp], and I Appreciate [X], (2) interrogative thanking such as May I thank you for [Xvp?] And Can I thank you for [Xvp?], and (3) imperative thanking such as Let me thank you for $[X p]$.

To obtain the frequency of the apology speech act in the ELT textbooks, Martinez's (2013) framework of speech act of apologizing was used. This speech act is divided into three categories: (1) declarative apologizing such as I am sorry [Xp], I was wrong [Xp], and I apologize $[X p],(2)$ imperative apologizing such as Excuse me, Pardon me, and Accept my apologies, and (3) Interrogative apologizing such as Will you forgive me [Xprep] and Can you forgive me [Xprep].

Based on these frameworks and by examining dialogue and conversation parts of the ELT textbooks, the occurrence of the speech acts as well as the main strategies used for each of them were counted. With regard to the speech act of thanking, whether it was (a) declarative, (b) imperative, or (c) interrogative, and for the speech act of apologizing, whether it was (a) declarative, (b) imperative, or (c) interrogative were specified.

The following extract taken from Chapter I: Good Morning. How are You? of When English Rings A Bell is an example of declarative thanking based on Martínez's (2013) framework:

Edo : Good Morning, Mr. Erry. The class is ready, Sir.

Mr. Erry : Morning Edo. Okay, thank you. 
The following extract taken from Chapter I: A New School Year of English on Sky is an example of declarative apologizing based on Martínez's (2013) framework:

Binsar's friend : Happy birthday, Binsar.

Binsar : :Thanks a lot.

Binsar's friend: You're welcome.

\section{FINDING AND DISCUSSION}

The first research question of the study was about the total frequency of pragmatic content with regard to speech acts of thanking and apologizing in the textbooks.

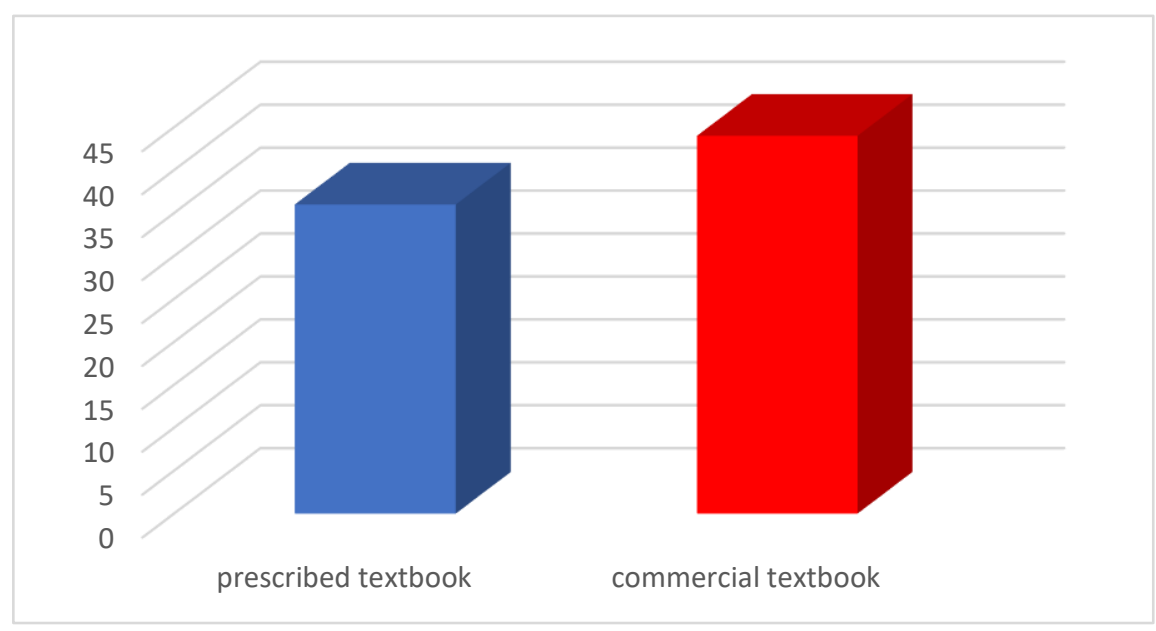

Figure 1. Overall frequency of the pragmatic content regarding speech acts of requesting, refusing, and apologizing in elementary ELT textbooks.

The frequency of pragmatic content in two ELT textbooks is shown in Figure I. based on the chart, English on Sky, the commercial textbook selected in this study has higher frequency of pragmatic content ( $\mathrm{f}=44$ ) than the prescribed textbook, When English Rings a Bell does ( $\mathrm{f}$ $=36)$.

The second research question was concerned with the frequency of two speech acts namely thanking and apologizing in the prescribed ELT textbook. To answer this question, the frequency is counted by using selected framework (Martinez, 2013).

Table 1. Frequency of Two Speech Acts in the prescribed textbook When English Rings a Bell

\section{Speech acts}

\begin{tabular}{ccc}
\hline Textbook & Thanking & Apologizing \\
\hline When English Rings a Bell & 27 & 9
\end{tabular}



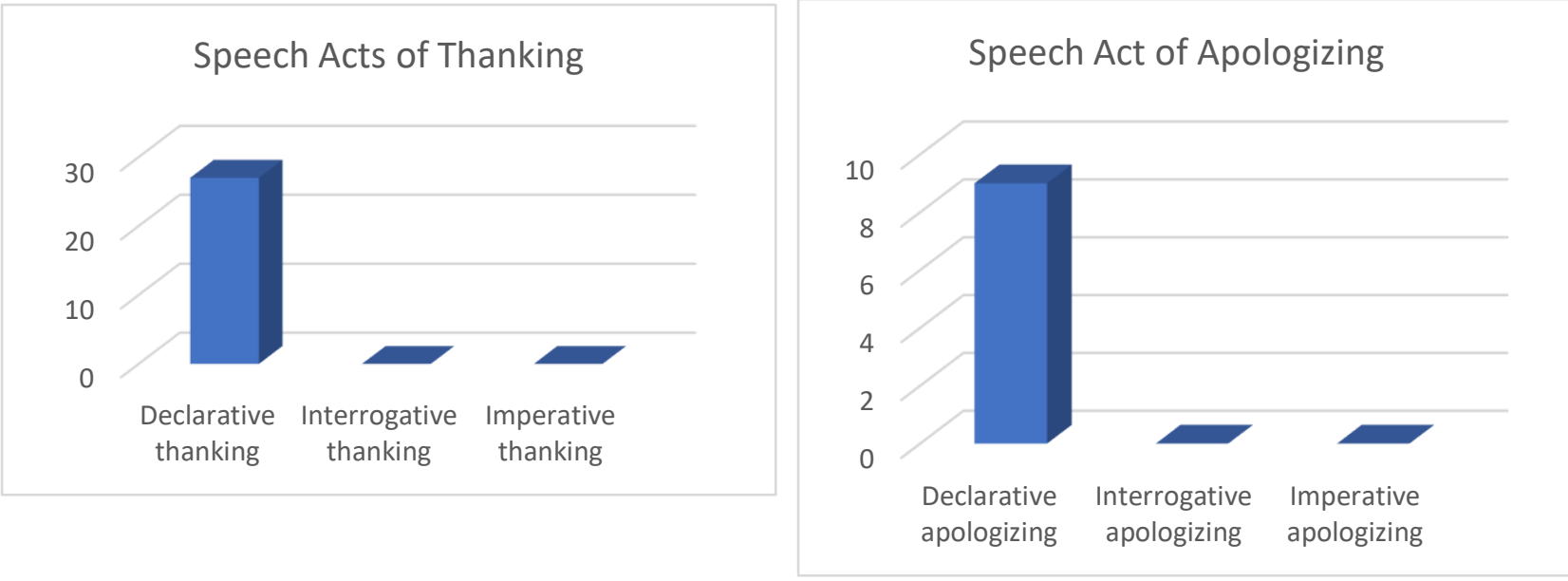

Figure 2. Frequency of the strategies used in each speech act in the prescribed textbook When English Rings a Bell.

Table I shows the frequency of the two speech acts which are counted from the conversation parts in the textbook When English Rings a Bell for Grade VII. From the table, it can be seen that the speech acts of thanking are used 27 times while the speech acts of apologizing are used 9 times. With regard to the strategies used in each speech acts, Figure II demonstrates how When English Rings a Bell put various speech act strategies in the conversation. As it can be seen, the strategy used in speech act of thanking is only declarative thanking, which is used in all 27 speech acts of thanking in the textbook. Similar to thanking strategies, strategies used in speech act of apologizing are all in the form of declarative, comprising 9 occurrences in the textbook.

Table 2. Frequency of Two Speech Acts in the commercial textbook English on Sky

\section{Speech acts}

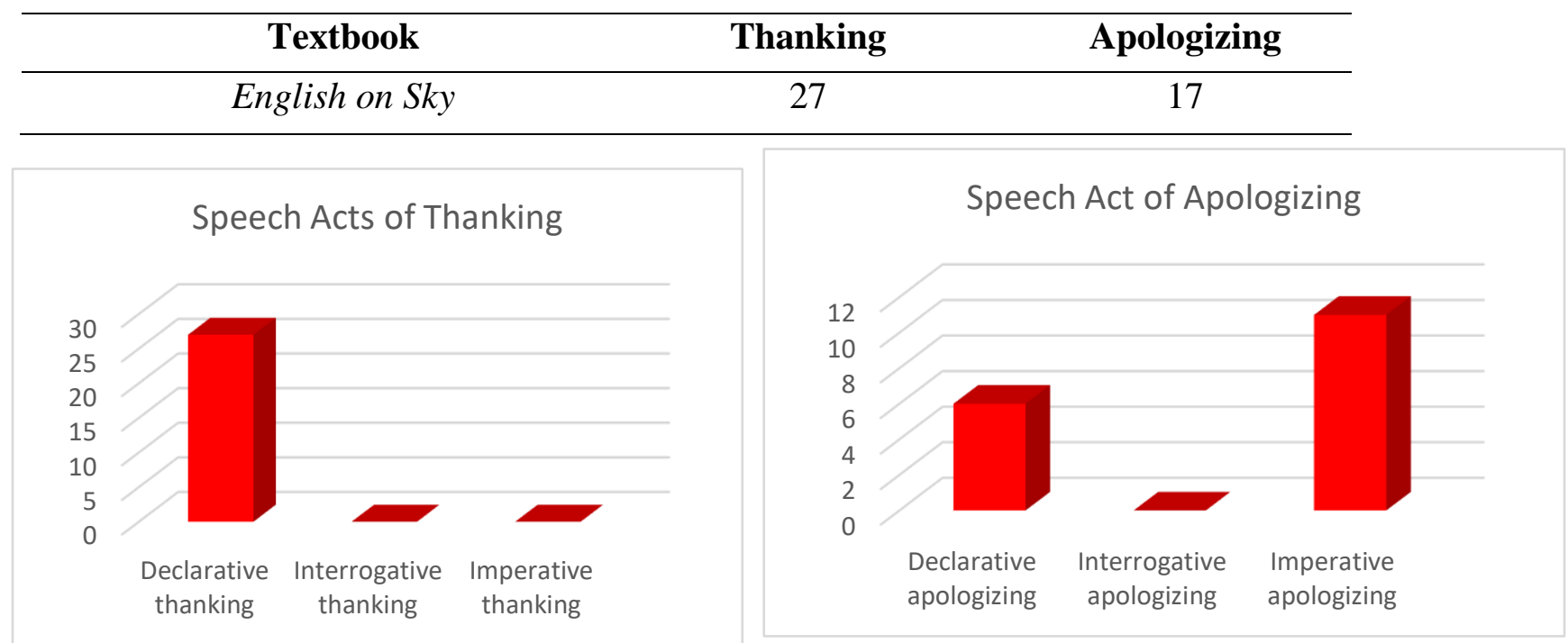

Figure 3. Frequency of the strategies used in each speech act in the commercial textbook English on Sky. 
The third research question aimed to obtain the frequency of speech acts of thanking and apologizing in English on Sky for Grade VII. Based on the analysis using selected framework (Martinez, 2013), the frequency of two speech acts is presented in Table II. As it can be seen, the speech acts of thanking and apologizing are used respectively 27 and 17 times. Those speech acts are manifested through different strategies in the textbook. The frequency of the strategies used in the speech acts of thanking and apologizing can be seen in Figure III above. As shown, from 27 occurrences of speech acts of thanking in English on Sky, all use declarative form of thanking. Different that of speech acts of thanking, the strategies used in the speech acts of apologizing in this textbook are more varied. Not only using declarative strategy, speech acts of apologizing in English on Sky also uses imperative strategy, with total of 11 occurrences out of 17 total speech acts of apologizing in the textbook.

\section{DISCUSSION}

Based on the result of the exploration of pragmatic content within two selected textbooks (the prescribed and the commercial one), there are several similarities shared by them. The first similarity is in the form of speech acts occurrence with regard to speech acts of thanking and apologizing. Insignificant difference of speech acts found in the textbooks (in terms of number) shows that the inclusion of pragmatic contents in these textbooks can be said as the same. Secondly, the occurrence of speech acts of thanking in both textbooks are the same (27 times) and has higher frequency compared to that of speech acts of apologizing. This is justified by the fact that one of skills which is expected to be mastered by students of grade VII is thanking and therefore occurrence of speech acts of thanking is higher.

Although When English Rings a Bell and English on Sky contain relatively the same number of pragmatic contents, there are noticeable findings on the exploration of these two ELT textbooks in the way they provide speech acts strategies. In When English Rings a Bell, the provision of strategies used in performing speech acts of thanking is only in the form of declarative. Expressions like "thank you" and "thanks" which are in the form of declarative are repetitively used in conversations while imperative and interrogative expressions like "may I thank you for..." and "let me thank you..." are absent in the textbook. Similarly, there is no imperative nor interrogative expressions found in English on Sky which has 27 occurrence of speech acts of thanking, meaning that all 27 occurrences are in the form of declarative strategy. Martinez (2013) suggests that the performance of thanking conforms to the realization of expressive acts, which show a tendency towards the use of declarative sentence. Even though imperative and interrogative sentences may be used in performing thanking, the incompatibility 
of thanking with the imperative lies on the nature of imperative sentence that it is more on the speaker's wish to get an action performed and the nature of interrogative sentences which is more on seeking for response from the addressee rather than revolving around the speakers' feeling as to an action already carried out. It is then justified why these ELT textbooks focus on providing declarative strategy in performing speech acts of thanking.

Another case of representation of strategies in these two textbooks deals with the use of strategies in performing speech acts of apologizing. Unlike the case of the provision of speech acts of thanking in the e-book entitled When English Rings a Bell and the print book entitled English on Sky which reveal quite similar findings, English on Sky seems to be better in providing variety of strategies in performing speech acts of apologizing. Having more speech acts occurrence compared to When English Rings a Bell does (17 compared to 9), the print book also provides varied strategies to perform speech acts of apologizing. While declarative sentences like "sorry" and "I am sorry" are the only type of strategy used in When English Rings a Bell, English on Sky provides both declarative and imperative strategies which can be used to perform speech acts of apologizing. "Sorry" and "Excuse me" are respectively the examples of declarative and imperative form used to apologize in English on Sky. Regarding the strategies used to perform apology, Martinez (2013) suggests that apologizing has the same preference with other expressive acts (such as thanking) that they tend to use declarative sentence type. However, while apologizing means that the speakers want to convey feelings of regret by asking the addressee to accept speakers' feeling, there is a greater tendency for the speakers to perform speech acts of apologizing by means of imperatives and interrogatives. Therefore, it can be said that the commercial textbook provides more varied option with regard to strategies to perform speech acts of apologizing compared to the prescribed textbook. Notwithstanding the finding that both When English Rings a Bell and English on Sky provide fairly sufficient pragmatic content, the provision of insufficient speech acts strategies in both textbooks seems to confirm the finding of research done by Diepenbrock and Derwing (2013), that ELT textbooks usually fail to represent different options which students had to take into account to perform a function. This lack of option lead to the EFL learners' difficulty in learning and using apology appropriately, as Khanlarzadeh \& Meihami (2015) suggest that different cultures may realize apology in different ways and poor attention within the textbooks may put L2 learners in trouble in the production and comprehension of it.

Regarding the strength and weakness of the examined textbooks, the findings of the study suggest that in terms of the inclusion of pragmatic contents, both When English Rings a Bell 
and English on Sky are in the same position, with the latter has slightly more pragmatic content occurrence than the former. With regard to the provision of strategies in performing speech acts of thanking, those textbooks share the same thing: declarative sentence type as an appropriate strategy is chosen as the one and only strategy but when it comes to the strategies of speech act of apologizing, English on Sky is in a better position. It provides not only declarative sentence type as the only strategy used in When English Rings a Bell but also imperative which tends to be appropriate to be used as a strategy to perform apologizing.

\section{CONCLUSION}

The study aims to examine the frequency of pragmatic content occurrence which is represented as speech acts of thanking and apologizing in ELT textbooks. To achieve the goal, a prescribed textbook entitled When English Rings a Bell and a commercial textbook entitled English on Sky were analyzed using Martinez's (2013) framework. Results of the study reveal that both textbooks have included sufficient pragmatic content to be learned by English language learners. However, in term of provision of strategies to perform speech acts (of thanking and apologizing), English on Sky is ahead of When English Rings a Bell since it includes more option. However, the coverage of strategies of those two textbooks is still considered minimal. Besides appropriate techniques such as drilling and group work are needed to help the students master certain skills (Rahmani, 2017), from the material aspect, the inclusion of different speech acts along with various strategies to perform the speech acts is paramount in second language learning (Meihami \& Khanlarzadeh, 2015). Therefore, material developers are suggested to include those things. For language teachers, it is suggested that the exposure of different speech acts and strategies to perform them need to be brought to fore.

There are some limitations of the present study which need to be considered if further research is to be done. First, the analysis of speech acts occurrence in this study does not include context of situation in which the speech acts are used due to limitation of time. Second, the textbooks selected are for grade VII and therefore the result of this study cannot be generalized. The last, pragmatic content analyzed in this study was only limited to speech acts of thanking and apologizing and therefore future study can examine the frequency or pattern for other types of speech act.

\section{REFERENCES}

Bardovi-Harlig, K. (2001). Evaluating the empirical evidence: Grounds for instruction in pragmatics? In K. Rose \& G. Kasper (Eds.), Pragmatics in Language Teaching (pp.13- 32). New York: Cambridge University Press. 
Brock, N. M., \& Nagasaka, Y. (2005). Teaching pragmatics in the EFL classroom? SURE you can! TESL Reporter, 38, 17-26.

Cheng, S. W. (2005). An exploratory cross-sectional study of interlanguage pragmatic development of expressions of gratitude by Chinese learners of English. A doctoral dissertation, University of Iowa.

Cohen, A.D. (2004). The interface between interlanguage pragmatics and assessment. Proceedings of the 3 Annual JALT Pan-SIG Conference, Tokyo, Japan

Delen, B., \& Tavil, Z. M. (2010). Evaluation of four coursebooks in terms of three speech acts: Requests, refusals and complaints. Procedia-Social and Behavioral Sciences, 9, 692-697. http://dx.doi.org/10.1016/j.sbspro.2010.12.219

Diepenbroek, G. L., \& Derwing, M. T. (2013). To what extent do popular ESL textbooks incorporate oral fluency and pragmatic development? TESL Canada Journal/Revue TESL du Canada, 30(7), $1-20$.

Ghoulami, J. (2015). Is there room for pragmatic knowledge in English books in Iranian high schools? English Language Teaching, 8(4).

Glaser, K. (2009). Acquiring pragmatic competence in a foreign language-Mastering dispreferred speech acts. Topics in Linguistics, 1(4), 50-57.

Kim, D., \& Hall, J. K. (2002). The role of an interactive book reading program in the development of second language pragmatic competence. Modern Language Journal, 86, 332-348.

Krippendorf, K. (2004). Content analysis.anintroduction to its methodology. Thousand Oaks, CA,Sage.

Lin, G.H.C. (2007). The significance of pragmatics. Mingdao Journal, 3(2), 91-102.

Lin, M.X. (2008). Pragmatic failure in intercultural communication and English teaching in China. China Media Research, 4(3), 43-52. Retrieved November, 2009, from http://www.chinamediaresearch.net/vol4no3/06Mei-xiao\%20Lin-final.pdf

Martínez, N.D.C. (2013). Illocutionary constructions in English: Cognitive motivation and linguistic realization. Bern, Switzerland: Peter Lang AG.

Meihami, H., \& Khanlarzadeh, M. (2015). Pragmatic Content in Global and Local ELT Textbooks: A Micro Analysis Study. SAGE Open. Retrieved December 2018 from https://doi.org/10.1177/2158244015615168

Rahmani, E.F. (2017). The effective teaching strategies to encourage young adolescent learners to speak English. Jurnal Pendidikan Bahasa, 6(1), 66-77.

Salazar Campillo, P. (2007). Examining Mitigation in Requests: A Focus on Transcripts in ELT Coursebooks. In E. Alcón Soler and M. P. Safont (Eds.), Intercultural Language Use and Language Learning (pp. 207-222). The Netherlands: Springer.

Saville-Troike, M. (2006). Introducing second language acquisition. Cambridge University Press. 
Silva, K.T.F.D. (2002) Do scripted textbook dialogues reflect native speaker discourse? An analysis of English textbook for adult students in Brazil. A thesis: The College of Arts and Sciences of Ohio University.

Usó-Juan, E. (2007). The presentation and practice of the communicative act of requesting in textbooks: Focusing on modifiers. In E. Alcón Soler and M. P. Safont (Eds.), Intercultural Language Use and Language Learning (pp. 223-243). The Netherlands: Springer.

Vasquez, C., Sharpless, D. (2009). The role of pragmatics in the master"s TESOL curriculum: Findings from a nationwide survey. TESOL Quarterly, 43(1), 5-28.

Vellenga, H. (2004). Learning pragmatics from ESL \& EFL textbooks: How likely? TESL-EJ, 8(2). Retrieved November 2009, from http://www-writing.berkeley.edu/TESL-EJ/ej30/a3.html

Wichien, S \& Aksornjarung, P. (2011) Pragmatic features in English course materials used a Thai university. Proceedings of the $3^{\text {rd }}$ International Conference on Humanities and Social Sciences, Songkhla, Thailand.

\section{Textbooks Surveyed}

Wachidah, S., Gunawan, A., Diyantari.,\& Khatimah, Y.R. (2017). When English rings a bell. Jakarta: Kemdikbud.

Mukarto, Kiswara, W., Santoso, S.B., \& Murwani, J.S. (2017). English on sky. Jakarta: Erlangga. 